\title{
Homo-heterojunction concept: From simulations to high efficiency solar cell demonstration
}

\author{
Tristan Carrere ${ }^{\mathrm{a}, \mathrm{b}, \mathrm{c}}$, Raphaël Lachaume ${ }^{\mathrm{b}}$, Quang Minh Thai ${ }^{\mathrm{b}}$, Marianne Coig ${ }^{\mathrm{d}}$, Jean-Paul Kleider ${ }^{\mathrm{b}}$, \\ Delfina Munoz ${ }^{\mathrm{a}, *}$ \\ ${ }^{\text {a } C E A-I N E S, ~ L I T E N, ~ L a b o r a t o i r e ~ H E T, ~} 50$ Avenue du Lac Léman, 73375 Le Bourget-du-Lac, France \\ ${ }^{\mathrm{b}}$ GeePs, UMR8507 CNRS, Centrale Supélec, Université Paris-Sud, Sorbonne Universités UPMC Univ Paris 6, 11 rue Joliot Curie, 91192 Gif-sur-Yvette cedex, France \\ ${ }^{\mathrm{c}}$ French Environment and Energy Management Agency, 20 avenue du Grésillé BP 90406, 49004 Angers cedex 01, France \\ d CEA-LETI, MINATEC Campus, 17 rue des Martyrs, 38054 Grenoble, France
}

\section{A R T I C L E I N F O}

\section{Keywords:}

Heterojunction solar cells

Boron implantation

\begin{abstract}
A B S T R A C T
The novel solar cell architecture called silicon homo-heterojunction (HHJ) cell is investigated combining experimental and simulation approaches. This structure intends to overcome the limitations of the silicon heterojunction technology regarding the amorphous/ crystalline silicon interface (p) a-Si:H/(i) a-Si:H / $(n)$ c-Si) by the addition of a $\left(p^{+}\right)$c-Si layer at the hetero-interface. First, the added $\left(p^{+}\right)$c-Si layer is experimentally investigated using boron implantation through the realization and characterization of symmetric solar cell precursors. An adapted process flow taking into account the $\left(p^{+}\right) \mathrm{c}$-Si profile optimization, the annealing effects on substrate degradation, and the impact on surface passivation, is deeply explored. Then, large area solar cells are processed and the solar cell performance are discussed in view of the data obtained on precursors and with the help of realistic numerical simulations. Overall, we observe that the HHJ solar cells exhibit a small performance improvement compared to reference heterojunction cells. In particular, a gain in the fill factor is observed, which is shown to be originated from both an improvement in field effect and a decrease of the vertical series resistance from the a-Si:H layers. The experimental data obtained on the processed homo-heterojunction solar cells confirm that this technology can lead to improved conversion efficiencies compared to the high quality reference heterojunction solar cells.
\end{abstract}

\section{Introduction}

Amorphous/crystalline silicon (a-Si:H/c-Si) heterojunction solar cells (SHJ) have already demonstrated to be a promising alternative to standard homojunction solar cells in terms of efficiency but also in terms of industrial production and cost [1,2]. In 2012, numerous laboratories and companies have strongly improved efficiencies and succeeded obtaining n-type SHJ solar cells with power conversion efficiencies above 21\% [3-7]. Moreover, results obtained in 2015 and 2016 by Kaneka surpassed the world record for crystalline silicon solar cells with more than $25 \%$ conversion efficiency $(25.1 \%$ [8] and $26.7 \%$ $[9,10]$ on large area regular and back contacted SHJ cells configurations, respectively) confirming the high potential of such structures for high efficiency cells and modules. The key of the SHJ technology is a simple and low temperature $\left(<200^{\circ} \mathrm{C}\right)$ process based on the deposition of a-Si:H layers onto a c-Si wafer used both to passivate the surface and to build the front junction and back surface field allowing for extremely high $\mathrm{V}_{\mathrm{OC}}[11]$.
However, in today's SHJ solar cells, the a-Si:H/c-Si interface passivation on the emitter side is identified as one of the most important issue $[12,13]$ limiting the SHJ cells performance specially because of the fill factor $(\mathrm{FF}) /$ open-circuit voltage $\left(\mathrm{V}_{\mathrm{OC}}\right)$ compromise. Indeed, the passivation of the surface (limiting the device $\mathrm{V}_{\mathrm{OC}}$ ) is strongly enhanced by the use of an intrinsic (i) a-Si:H layer. However, such layer is resistive and impacts negatively the fill factor (FF) increasing vertical series resistances when increasing the thickness, while also impacting the short circuit current due to parasitic absorption, especially in the front emitter configuration. Thus, the ( $i)$ and ( $p$ ) a-Si:H layer thicknesses are optimized for the compromise between passivation (low interface defect density $\mathrm{D}_{\mathrm{it}}$ ), doping (strong field effect) and vertical conduction. Additionally, the role of the transparent conductive oxide (TCO) $[14,15]$ is required to collect laterally the charges (to insure low lateral series resistances) and to achieve an effective $\mathrm{Metal} / \mathrm{TCO} /(\mathrm{i} / \mathrm{p})$ a-Si:H/c-Si contact (correlated to vertical series resistance) [16].

Different approaches have been proposed to improve the passivation/field effect compromise, for instance, improving cleaning [13],

\footnotetext{
* Corresponding author.

E-mail address: delfina.munoz@cea.fr (D. Munoz).
} 
tuning the (i) a-Si:H layers structures and properties $[17,18]$ or band management modifications using silicon based amorphous alloys [19-22].

An alternative option to improve the field effect is by the addition of a thin and highly doped $\left(p^{+}\right)$c-Si region underneath the $(i)$ a-Si:H passivation layer modifying the crystalline silicon space charge region. The resulting structure is called a homo-heterojunction (HHJ) for it combines a homojunction profile to improve band bending and vertical carrier collection with the amorphous hetero-emitter.

In previous numerical simulation studies [23], it was shown that, compared to the SHJ cell, the HHJ cell exhibits a higher open-circuit voltage and is less sensitive to interface defects. These features have been evidenced to originate from the additional field effect passivation brought by the $\left(p^{+}\right) \mathrm{c}$-Si region. Additionally, the HHJ cell fill factor is also improved and less influenced by interface defects [23]. Such improvements were also observed by simulations by other authors on similar homo-heterojunction cells with insertion of a highly doped crystalline layer at the emitter of either n-type or p-type silicon solar cells $[24,25]$.

Concerning experimental results, the HHJ cells fabricated so far did not succeed to surpass the performance of SHJ cells because of their lower $\mathrm{V}_{\mathrm{OC}}$ due to increased recombination after the $\left(p^{+}\right) \mathrm{c}$-Si processing $[26,27]$. Such increased recombination could take place in the strongly doped $\left(p^{+}\right)$c-Si region or could originate from a low $\left(p^{+}\right) \mathrm{c}-\mathrm{Si} /(i) \mathrm{a}-$ $\mathrm{Si}: \mathrm{H}$ chemical passivation. They can also appear in the substrate due to the creation of additional defects related to the high temperature needed for the $\left(p^{+}\right)$c-Si layer processing (epitaxy, post-implantation annealing or diffusion) [28].

In this work, we use boron implantation to produce the $\left(p^{+}\right) \mathrm{c}-\mathrm{Si}$ layer. In a first part, ion implantation parameters are optimized using effective lifetime measurements on symmetrical $\left(p^{+}\right) \mathrm{c}-\mathrm{Si} /(n) \mathrm{c}-\mathrm{Si} /\left(p^{+}\right)$ c-Si samples. Then, in a second part we fabricate HHJ cells and standard SHJ cells. For the first time we were able to obtain HHJ cells exhibiting slightly improved conversion efficiencies compared to the SHJ ones. Results are discussed and explained in the light of further numerical simulations.

\section{Experimental details}

\subsection{Symmetrical $p^{+} n p^{+}$samples}

Symmetrical $\left(p^{+}\right)$c-Si $/(n)$ c-Si $/\left(p^{+}\right)$c-Si samples $\left(\mathrm{p}^{+} \mathrm{np}^{+}\right)$are first processed by implanting boron (B) with a beam-line Varian VIISta ${ }^{\circledR}$ HCP implanter in 160-180 $\mu$ m thick n-type textured $\mathrm{Cz}$ pseudo-square 156 $\times 156 \mathrm{~cm}^{2} \mathrm{c}$-Si substrates with initial resistivity ranging from 3.0 to $4.0 \Omega \mathrm{cm}$. Various energies and doses have been tested to obtain different profiles. In particular, c-Si wafers have been taken from the second quarter of the $\mathrm{Cz}$ ingot to avoid strong oxygen and metallic impurities known to be detrimental for substrate lifetime when high temperature steps are used during processing [29]. After an $\mathrm{HF}^{-\mathrm{O}_{3}}$ cleaning step, boron is activated around $950{ }^{\circ} \mathrm{C}$ during $15 \mathrm{~min}$ in a nitrogen atmosphere. Such low activation temperature has been chosen following a previous work in order to limit bulk substrate damages [28]. By comparing the secondary ion mass spectroscopy (SIMS) results (Fig. 1) with that of electrochemical capacitance-voltage (ECV) (not shown here), the boron atoms were checked to be fully active [30]. Implantation parameters, boron dose and boron surface concentration deduced from SIMS are summarized in Table 1 for five batches $\left(\mathrm{HHJ}_{1}\right.$ $\mathrm{HHJ}_{5}$ ), each batch consisting in three wafers.

Subsequent to the annealing step at $950{ }^{\circ} \mathrm{C},\left(p^{+}\right)$c-Si surfaces are passivated using different stacks and layers:

- a 8/72 nm-thick $\mathrm{AlO}_{\mathrm{x}} / \mathrm{SiN}_{\mathrm{x}}: \mathrm{H}$ stack, deposited by atomic layer deposition (ALD) in a Beneq equipment at room temperature and high temperature plasma enhanced chemical vapor deposition (PECVD) in a Centrotherm tool at $450^{\circ} \mathrm{C}$, respectively,

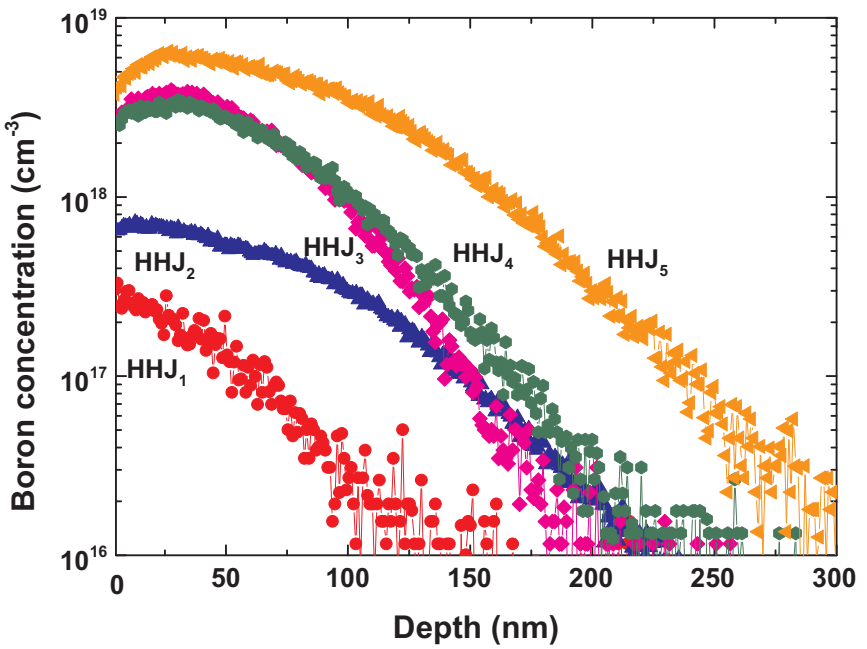

Fig. 1. SIMS measurement of the studied boron implantation profiles, on polished n-type c-Si substrates.

Table 1

Summary of implantation energy and dose conditions tested in this work, with measured boron dose and surface concentration from SIMS measurements after the annealing and the surface cleaning steps, and the corresponding calculated sheet resistance. These values are valid for polished n-type substrates. For textured substrates the implantation dose is multiplied by 1.7 in order to obtain similar sheet resistance from the implanted doped region.

\begin{tabular}{llllll}
\hline $\begin{array}{l}\text { Batch } \\
\text { name }\end{array}$ & $\begin{array}{l}\text { Implantation } \\
\text { energy }\end{array}$ & $\begin{array}{l}\text { Implanted B } \\
\text { dose }\end{array}$ & $\begin{array}{l}\text { Measured B } \\
\text { dose }\end{array}$ & $\begin{array}{l}{[\mathrm{B}]^{\text {surface }}} \\
\mathrm{cm}^{-2}\end{array}$ & $\begin{array}{l}\mathrm{R}_{\text {sh }} \\
\text { (Calculated } \\
\text { from sIMS) } \\
\Omega\end{array}$ \\
\hline $\mathrm{cm}^{-2}$ & 1 & $1.0 \times 10^{13}$ & $1.7 \times 10^{12}$ & $4.0 \times 10^{17}$ & $1.4 \times 10^{4}$ \\
$\mathrm{~cm}^{-3}$ & $1.0 \times 10^{13}$ & $1.0 \times 10^{13}$ & $7.5 \times 10^{17}$ & $4.2 \times 10^{3}$ \\
$\mathrm{HHJ}_{2}$ & 10 & $1.0 \times 10^{14}$ & $3.1 \times 10^{13}$ & $3.0 \times 10^{18}$ & $1.7 \times 10^{3}$ \\
$\mathrm{HHJ}_{3}$ & 1 & $5.0 \times 10^{13}$ & $3.0 \times 10^{13}$ & $3.0 \times 10^{18}$ & $1.7 \times 10^{3}$ \\
$\mathrm{HHJ}_{4}$ & 5 & $1.0 \times 10^{14}$ & $7.3 \times 10^{13}$ & $5.0 \times 10^{18}$ & $8.5 \times 10^{2}$ \\
$\mathrm{HHJ}_{5}$ & 10 & & & & \\
\hline
\end{tabular}

- a-Si:H layers deposited at $200{ }^{\circ} \mathrm{C}$ by PECVD in a Jusung cluster tool :

o a $18 \pm 1 \mathrm{~nm}$ thick (i) a-Si:H layer,

o a $20 \pm 1 \mathrm{~nm}$ thick $(i / p)$ a-Si:H stack,

It is already known that thanks to the $\mathrm{AlO}_{\mathrm{x}}$ negative charges, the $\mathrm{AlO}_{\mathrm{x}} / \mathrm{SiN}_{\mathrm{x}}: \mathrm{H}$ stack passivates very efficiently B-doped c-Si surfaces [31] and will serve as our passivation reference. The $(i / p)$ a-Si:H stack is the same as used in SHJ solar cells at INES [8] and will be used for the realization of HHJ cells.

For comparison purposes, we also processed two other batches of symmetrical structures, that we designate as $\mathrm{SHJ}_{\mathrm{REF}}$ and $\mathrm{SHJ}_{950}{ }^{\circ} \mathrm{C}$ in the following. These are reference samples without any boron implantation and using the standard cleaning procedure developed at INES for the fabrication of silicon heterojunction solar cells [8], except that $\mathrm{SHJ}_{950}{ }^{\circ} \mathrm{C}$ has been submitted to the same annealing step at $950^{\circ} \mathrm{C}$ as the HHJs samples (before deposition of the surface passivation layers) in order to investigate the effect of such annealing on the wafer properties.

Injection dependent effective minority carrier lifetime curves are obtained using a WCT-120 Sinton Instrument setup. For an easy and rapid comparison these curves can be used to extract the effective lifetime at an injection level of $10^{15} \mathrm{~cm}^{-3}$ [32] or the implied opencircuit voltage (i- $\left.\mathrm{V}_{\mathrm{OC}}\right)$ [33].

For samples with the $(i / p)$ a-Si:H passivation stack, we also deposited top co-planar electrodes made of a bi-layer of indium tin oxide (ITO) covered with silver, with various interspacing distances. We the applied the transfer length method (TLM) in order to get insight into 


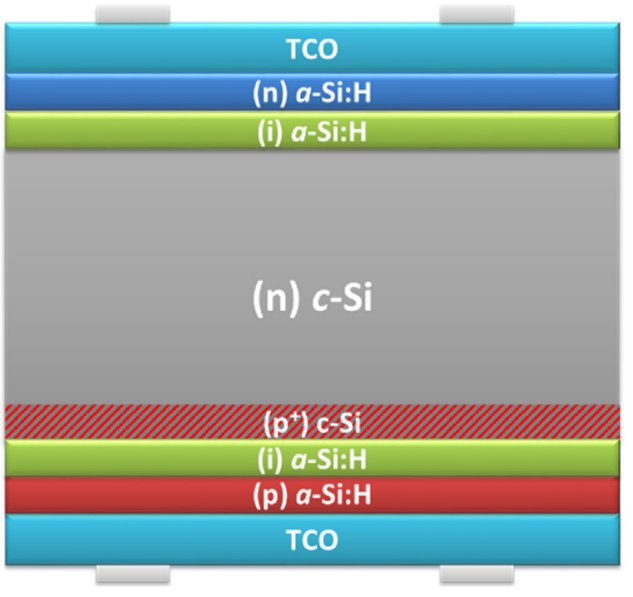

Fig. 2. Sketch of the HHJ solar cell in the rear emitter configuration.

conduction properties [34,35].

From the SIMS profiles of Fig. 1 we calculated the implanted boron dose and compared it to the nominal dose (see Table 1). One can note that the two values are not identical, the measured dose being lower than the nominal one. This difference can originate from matrix atoms sputtering due to ion implantation or from the surface etching due to post-implantation and post-annealing cleaning routines [36].

\subsection{Solar cells fabrication}

Large area (on $156 \mathrm{~mm}$ pseudo square wafers) SHJ and HHJ solar cells are processed in a rear emitter configuration (see Fig. 2) at INES pilot line "Labfab" [37] with an industrial process. To finish the solar cell, after the amorphous layers processing, ITO is deposited by PVD on both sides using masks covering the edges to avoid parasitic shunt resistances. Then, solar cells are screen printed with a 4 bus bars bifacial configuration. Solar cells are characterized using IV measurements under 1-sun AM1.5 illumination conditions with an Aescusoft solar simulator. In order to get further insight into the new cell features, Suns$\mathrm{V}_{\mathrm{OC}}$ [38] and photoluminescence (PL) [39] measurements are also performed. Series resistances are extracted from the comparison between IV and SunsVoc as suggested by [40].

\section{Results and discussions}

\section{1 a-Si:H passivation on boron-doped surfaces}

First, the amorphous silicon passivation quality on the $\left(p^{+}\right) \mathrm{c}-\mathrm{Si}$ layer needs to be evaluated. We aim at obtaining passivations of the new hetero-interface of at least similar quality as for standard SHJ cells. This is required in order to benefit from the $\left(p^{+}\right)$c-Si layer addition in terms of collection while guaranteeing high $\mathrm{V}_{\mathrm{OC}}$. The effective lifetime as a function of excess carrier density of $\mathrm{p}^{+} \mathrm{np}^{+}$samples is plotted in Fig. 3 for each passivation system and for the five implantation conditions and the two reference samples.

In Fig. 3a, effective lifetime curves of HHJ samples passivated by the $\mathrm{AlO}_{\mathrm{x}} / \mathrm{SiN}_{\mathrm{x}}: \mathrm{H}$ system are found close to those of the reference samples.

The difference between samples is larger at low injection level, which can be explained by a difference in field effect whether the $\mathrm{AlO}_{\mathrm{x}} /$ $\mathrm{SiN}_{\mathrm{x}}: \mathrm{H}$ stack is deposited directly onto the n-type c-Si wafer or on the implanted $\mathrm{p}+$ region. The difference is weaker in the intermediate to high injection level (HIL) range (for excess carrier densities larger than $10^{15} \mathrm{~cm}^{-3}$ ), where field effect passivation is less prominent. This shows that all implanted $\left(p^{+}\right) \mathrm{c}$-Si bulk regions are lowly defective and do not strongly intrinsically limit the effective lifetime of the samples. Therefore, all tested implantation conditions are potentially suitable for the HHJ application where we can expect high implied- $\mathrm{V}_{\text {oc }}$ values.
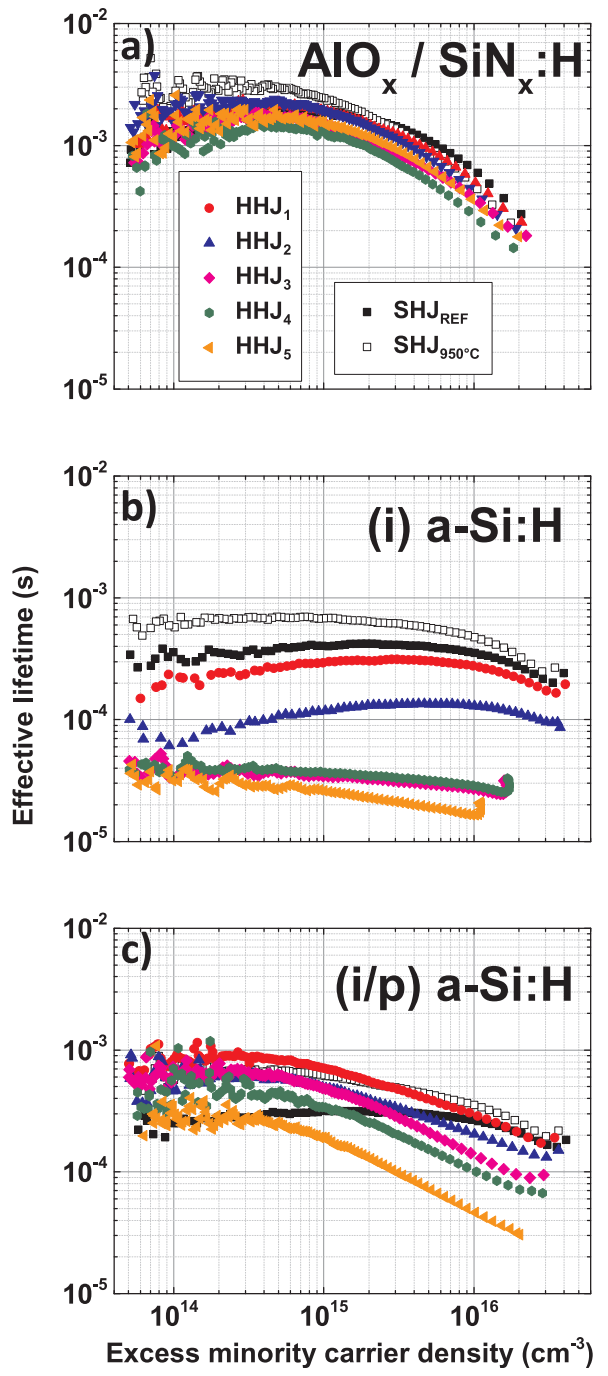

Fig. 3. Effective lifetime as a function of the excess minority carrier density for all symmetric samples with the different $\mathrm{B}$ profiles for a) the $\mathrm{AlO}_{\mathrm{x}} / \mathrm{SiN}_{\mathrm{x}}: \mathrm{H}, \mathrm{b}$ ) the (i) a-Si:H and c) the (i/p) a-Si:H passivation stacks.

However, from Fig. 3b, the samples with implanted profiles (HHJ samples) have lower effective lifetimes than both reference samples $\left(\mathrm{SHJ}_{\mathrm{REF}}, \mathrm{SHJ}_{950}{ }^{\circ} \mathrm{C}\right)$ when passivated by (i) a-Si: $\mathrm{H}$. This decrease is observed on the whole injection level range, meaning that the chemical passivation is decreased for the boron-doped surfaces (i.e. they have higher $\mathrm{D}_{\mathrm{it}}$ ).

Using the $(i / p)$ a-Si:H passivation stack (that is used in heterojunction solar cells) we observe an increase in the effective lifetime at low injection level compared to the samples using only the single (i) aSi:H passivation layer (Fig. 3c), while the increase at high injection is less pronounced, which is a signature of the field effect passivation [41], indicating that the ( $p)$ a-Si:H layer adds a field effect with a significant contribution to the passivation, although less pronounced than the one provided by the AlOx/SiNx:H passivation stack. From this figure one can already deduce that $\mathrm{HHJ}_{1}$ and $\mathrm{HHJ}_{2}$ exhibit comparable lifetime values at high injection as the SHJ samples and better values at low injection. They are thus expected to improve the solar cells FF and pseudo-FF (pFF) values [42], and will be privileged for the realization of solar cells which results will be described in Section C.

For a better readability and analysis of the lifetime curves at both low and high injection conditions, Fig. 4 summarizes the values of effective lifetime at an excess carrier density of $10^{15} \mathrm{~cm}^{-3}, \tau^{\mathrm{LL}}$ and the values of implied-open-circuit voltage $\mathrm{i}-\mathrm{V}_{\mathrm{OC}}$, which are representative 


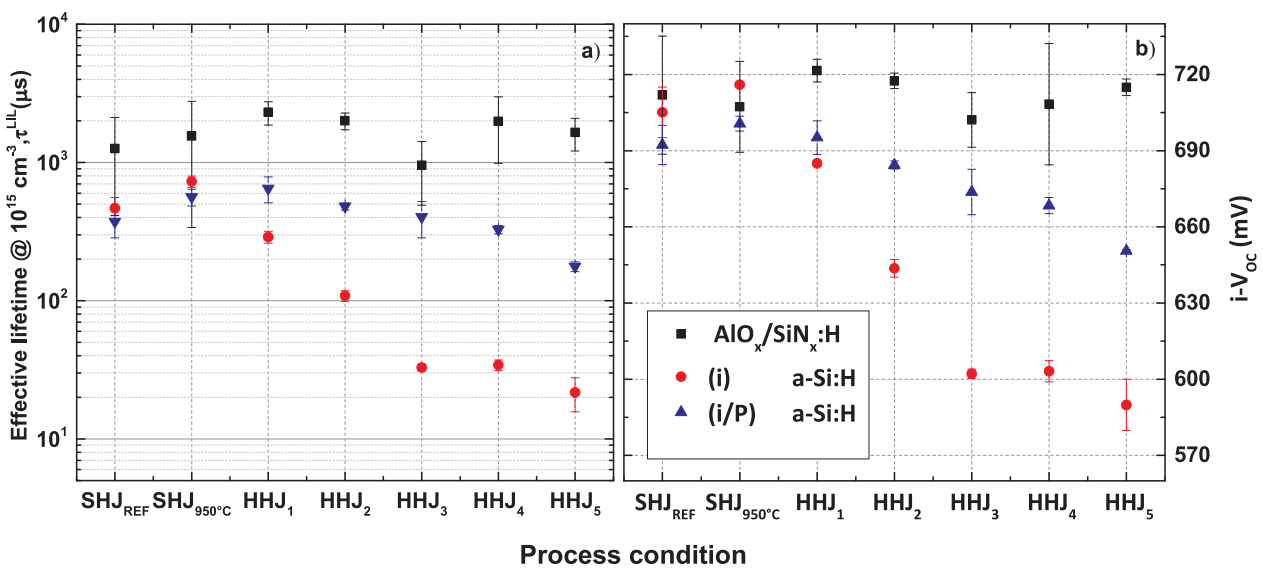

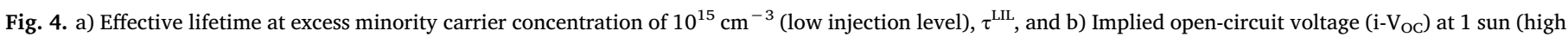
injection level) for different passivation stacks.

of the low and high injection regimes, respectively.

First of all, by comparing the results of $\mathrm{SHJ}$ REF and $\mathrm{SHJ}_{950}{ }^{\circ} \mathrm{C}$ we note that $\tau^{\mathrm{LIL}}$ is slightly increased after annealing whatever the passivation system. Such improvement probably originates from oxygen-related phenomena in the c-Si wafer. Dissolution of as-grown thermal donors (TD) upon annealing has been characterized by a resistivity increase from 2.5 to $6 \Omega \mathrm{cm}$, corresponding to an initial TD concentration of $5 \times$ $10^{14} \mathrm{~cm}^{-3}$. Such phenomenon occurs at temperatures above $600{ }^{\circ} \mathrm{C}$ [43] and is known to suppress recombination-active defects [44]. Complementary tests with very high passivation (i)/(n) stack (not shown) demonstrate that TD were shown to limit $\tau^{\mathrm{LIL}}$ at $2 \mathrm{~ms}$ at the concentration of $5 \times 10^{14} \mathrm{~cm}^{-3}$ [45]. Therefore, assuming samples to have the same interface recombination velocities for $\mathrm{SHJ}_{\text {ref }}$ and $\mathrm{SHJ}_{950^{\circ} \mathrm{C}}$, TD dissolution is likely to explain the effective lifetime increase upon annealing. This also evidences that the bulk lifetime plays a significant role in the device effective lifetime limitation.

Compared to $\mathrm{AlO}_{\mathrm{x}} / \mathrm{SiN}_{\mathrm{x}}: \mathrm{H}$, the limited a-Si:H passivation on the $\left(p^{+}\right)$c-Si surface is a striking result of this experiment. Such effect was previously evidenced for highly doped homo-emitters obtained from homojunction-type boron diffusion with saturation current densities $\mathrm{J}_{0 \mathrm{e}}$ above $100 \mathrm{fAcm}^{-2}$ and sheet resistances lower than $200 \Omega / \Upsilon[46,47]$.

In our experiments, the boron profiles in the HHJ samples are softer, with $\mathrm{J}_{0 \mathrm{e}}$ values lower than $60 \mathrm{fAcm}^{-2}$ for the $\mathrm{AlO}_{\mathrm{x}} / \mathrm{SiN}_{\mathrm{x}}: \mathrm{H}$ passivation stack. Interestingly, in the tested boron surface concentration ([B] ${ }^{\text {Surf }}$ ) range $\tau^{\mathrm{LIL}}$ exhibits a linear dependence on $[\mathrm{B}]^{\text {Surf }}$ in a log-log plot (see Fig. 5: Effective lifetime at excess minority carrier concentration of $1015 \mathrm{~cm}-3$ (low injection level), $\tau^{\mathrm{LIL}}$, as a function of the boron surface concentration for the various passivation layers: (i) a-Si: $\mathrm{H},(\mathrm{i} / \mathrm{p}$ ) a-Si:H

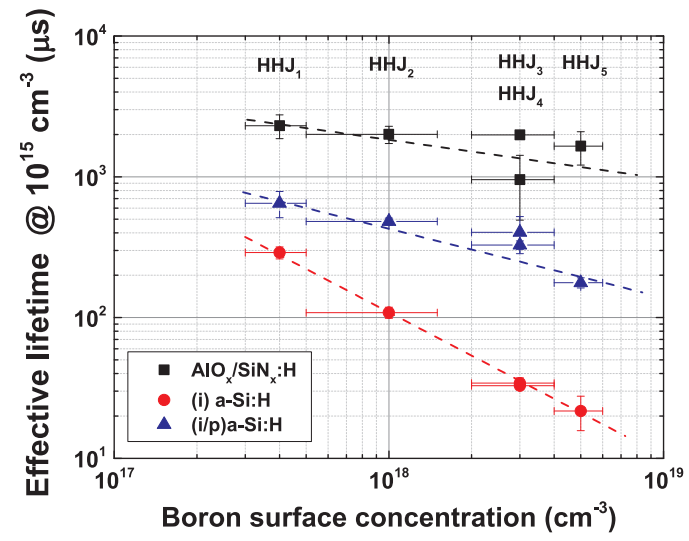

Fig. 5. Effective lifetime at excess minority carrier concentration of $10^{15} \mathrm{~cm}^{-3}$ (low injection level), $\tau^{\mathrm{LIL}}$, as a function of the boron surface concentration for the various passivation layers: (i) a-Si:H, (i/p) a-Si:H and $\mathrm{AlO}_{\mathrm{x}} / \mathrm{SiN}_{\mathrm{x}}: \mathrm{H}$. and AlOx/SiNx: H.).

To our knowledge no study has so far evidenced such a behavior. This suggests a power law dependence $\tau^{\mathrm{LLL}} \sim\left([\mathrm{B}]^{\text {Surf }}\right)^{\gamma}$. While $\gamma$ is close to zero for the $\mathrm{AlO}_{\mathrm{x}} / \mathrm{SiN}_{\mathrm{x}}: \mathrm{H}$ passivation stack, where field effect passivation can make recombination less sensitive to interface defects and thus to $[\mathrm{B}]^{\text {Surf }}, \gamma$ is approximately -0.5 and -1 for the $(i / p)$ a-Si:H and (i) a-Si:H passivation layers, respectively. The latter indicates that interface defect densities increase proportionnaly to the surface boron concentration and that (i) a-Si:H provides a limited chemical passivation on strongly boron-doped surfaces.

We have evidenced in this first experiment a limited chemical passivation of a-Si:H on strongly boron-doped surfaces. Interestingly, Carstens et al. demonstrated that tuning the (i) a-Si:H deposition and annealing temperature could improve the passivation on boron-doped c-Si surfaces [47]. The passivation level is maximized when a-Si:H is deposited at low temperature. Thus, the involved mechanism seems to be related to as-deposited a-Si:H hydrogen content and $\mathrm{H}$ configuration variation from poly-hydride to mono-hydride configurations upon annealing [17]. $\mathrm{J}_{0 \mathrm{e}}$ values as low as $30 \mathrm{fAcm}^{-2}$ for $30 \mathrm{~nm}$ thick (i) a-Si:H passivation on a stronger diffused homo-emitter $\left(R_{\square}=90 \Omega / \square\right)$ have been reported using a $150{ }^{\circ} \mathrm{C}$ deposition temperature and post-deposition annealing of $5 \mathrm{~min}$ at $350^{\circ} \mathrm{C}$ [47]. Additional post-process annealing steps up to $300{ }^{\circ} \mathrm{C}$ have been performed on our samples but no effective lifetime increase has been observed. This result is likely to originate from the need of large $\mathrm{H}$ content in a-Si:H after deposition in order to enable passivation improvements upon annealing [17]. Thus deposition of a-Si:H at lower temperature could be envisaged in the future for further passivation improvements.

\subsection{Effect of the $(p+)$ c-Si region in conduction issues}

TLM measurements have been performed on samples with the $(i / p)$ a-Si:H stack. From such measurements one can extract a sheet resistance $\left(R_{\text {sh }}\right)$ [34], that is related to the lateral current flow between the two top electrodes, either in the a-Si:H or in the c-Si regions. When samples have no implanted $\left(p^{+}\right) \mathrm{c}$-Si region it was shown that the measured sheet resistance reflects conduction in the strong hole inversion layer at the c-Si surface which is caused by the strong band bending implied by the top ( $i / p)$ a-Si:H stack [48], while lateral conduction in a-Si:H is negligible due to the low carrier mobility and low effective doping efficiency in this material. When a $\left(p^{+}\right) \mathrm{c}$-Si region is processed, both the inversion layer and the $\left(p^{+}\right)$c-Si region can participate to the measured sheet resistance.

Fig. 6 shows that the sheet resistance is decreased approximately one order of magnitude for HHJ1 and by a factor of about 300 for HHJ2 compared to the reference samples without $\left(p^{+}\right) \mathrm{c}$-Si region. This proves that insertion of the $\left(p^{+}\right)$c-Si region has a strong effect on the 


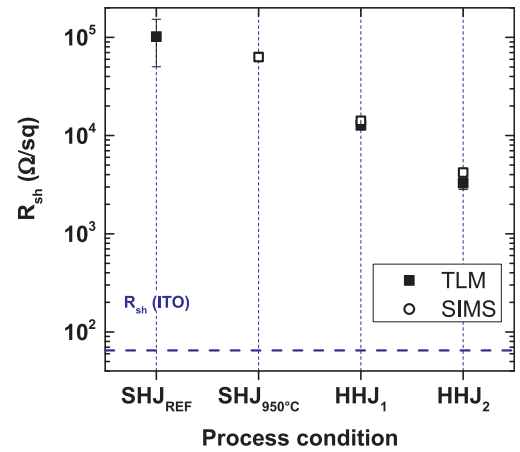

Fig. 6. Measured sheet resistance $\left(\mathrm{R}_{\mathrm{sh}}\right)$, extracted from TLM measurements compared to sheet resistance calculated from SIMS measurement.

band bending and on the Fermi level position at the c-Si surface. Moreover, the $\mathrm{R}_{\mathrm{sh}}$ values measured from TLM and calculated from SIMS profiles are quite identical. For the latter calculation we first determine the resistivity profile from the measured boron profile (remember that the boron atoms are known to be fully activated from the comparison of ECV and SIMS profiles), with the doping dependent carriers mobility being calculated from the Arora's model [49]. The sheet resistance is then obtained from the reciprocal of the integrated $\left(p^{+}\right)$c-Si layer conductivity. We however notice that the sheet resistance of the $\mathrm{HHJ}_{2}$ samples still remains high (by more than one order of magnitude) compared to the ITO sheet resistance, which is at about $65 \Omega / \square$. Thus no significant lateral current transport improvement is expected in $\mathrm{HHJ}_{1}$ and $\mathrm{HHJ}_{2}$ solar cells compared to the reference SHJ cells, and the ITO layer is still mandatory. Only for the strongly implanted $\mathrm{HHJ}_{5}$ the sheet resistance is decreased to a level of $60 \Omega / \square$ (not shown in this figure) equivalent to that of ITO, but, as mentioned above, such a high implantation level is detrimental regarding passivation issues.

\subsection{Solar cells results}

Fig. 7: Photovoltaic performance of SHJ and HHJ cells: open-circuit voltage, short circuit current density, fill factor, efficiency, and series resistance. Error bars are standard deviations on at least three samples.

This summarizes the photovoltaic output parameters (open-circuit voltage, short circuit current density, fill factor) of all processed cells and includes the $\mathrm{pFF}$ values extracted from Suns- $\mathrm{V}_{\mathrm{OC}}$ measurements and the calculated series resistances.

HHJ and SHJ cells have similar $\mathrm{J}_{\mathrm{SC}}$ values (variability is linked to screen printing process). This is consistent with numerical simulations where no short circuit current loss is expected in rear emitter HHJ cells compared to the reference SHJ cells [23].

Open-circuit values of $\mathrm{SHJ}_{\mathrm{REF}}, \mathrm{SHJ}_{950}{ }^{\circ} \mathrm{C}$ and $\mathrm{HHJ}_{1}$ samples are very similar, meaning that the $\mathrm{HHJ}_{1}$ cells do not exhibit increased recombination in the homo-emitter and at the hetero-interface. The $\mathrm{HHJ}_{2}$ cells have a slightly lower $\mathrm{V}_{\mathrm{OC}}$ because of a lower interface passivation, as observed in the lifetime curves on the symmetrical cell precursors (see Fig. 3b).

The fill factor of $\mathrm{HHJ}_{1}$ cells is slightly improved, by $0.9 \%$ and $0.6 \%$ abs. as compared to $\mathrm{SHJ}_{\mathrm{REF}}$ and $\mathrm{SHJ}_{950}{ }^{\circ} \mathrm{C}$ cells, respectively. This $\mathrm{FF}$ improvement is explained by both a pFF increase and a series resistance decrease.

To disregard process induced defectivity issues in $\mathrm{FF}$ and $\mathrm{V}_{\text {oc }}$ values, PL images have been performed (Fig. 8).

A striking feature of the figure is that all cells that experienced an annealing step exhibit dark regions principally at the edges due to increased recombination. This originates from the increased number of process steps that implies more samples manipulation and leads to enhanced process induced defectivity. However this is counter balanced by an improved quality of the c-Si material, which was revealed by the measurements on the cell precursors (Fig. 3 et 4). Indeed lifetime

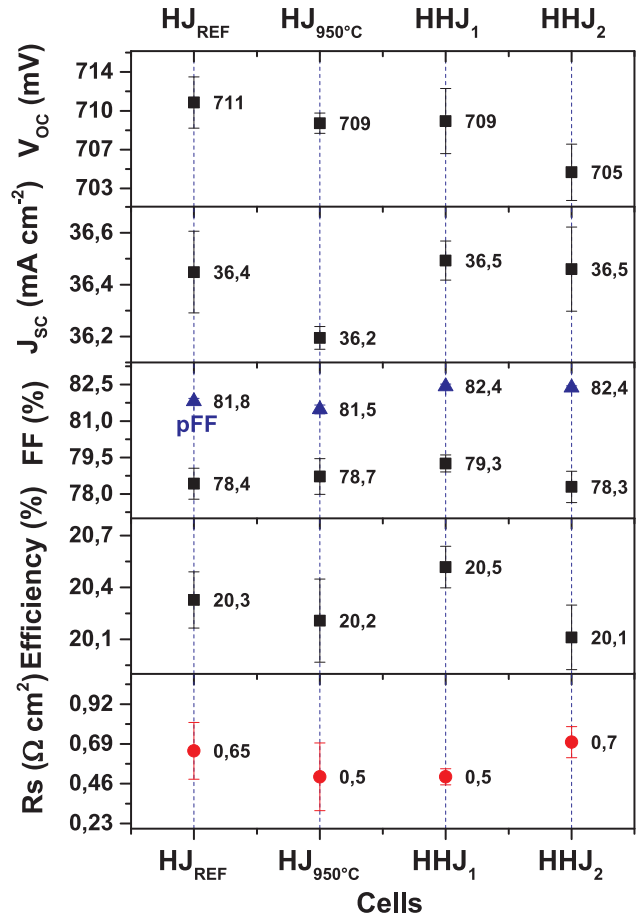

Fig. 7. Photovoltaic performance of SHJ and HHJ cells: open-circuit voltage, short circuit current density, fill factor, efficiency, and series resistance. Error bars are standard deviations on at least three samples.

measurements on the cell precursors are performed in the center of the wafer that is less impacted by sample manipulation. It means that we could reach even higher $\mathrm{V}_{\mathrm{oc}}$ and $\mathrm{FF}$ in the implanted samples if we suppressed the process induced defectivity by improving sample handling.

\subsection{General discussion - numerical simulations}

In order to gain further insight into the HHJ cells working principle and to discuss experimental results, numerical simulations of both the SHJ and HHJ cells are performed.

\subsubsection{Simulation models and parameters}

Solar cells simulations are performed using Silvaco Atlas. SHJ cell layer parameters have been taken primarily from Varache's work [50] and have then be adapted in order to closely represent experimental cells as fabricated at INES. They are described in Table 2 . The density of states (DOS) in the doped a-Si:H layers follows the defect-pool model proposed by Powell and Deane [51]. For the dangling bonds defects, this leads to Gaussian distributions located at $1.45 \mathrm{eV}$ from the valence band edge $\left(E_{V}\right)$. Because of the statistics for monovalent states used in the modeling, amphoteric dangling bond states are represented as two Gaussian distributions of monovalent states shifted by the correlation energy taken equal to $0.2 \mathrm{eV}$. Due to the very low thickness of (i) a-Si:H layers, the Fermi level $\left(\mathrm{E}_{\mathrm{F}}\right)$ position in these layers is much closer from $E_{V}$ than from the conduction band $\left(E_{C}\right)$. Therefore, according to the defect-pool model the energetic position of localized states originating from dangling bonds is the same as for the doped adjacent layers. However, the absolute values of the Gaussian distributions are taken much lower.

At front and back hetero-interfaces, defects are introduced using a $1 \mathrm{~nm}$ thick highly defective c-Si interfacial layer containing two Gaussian distributions of localized states. The donor-like and the acceptor-like Gaussian distributions have their respective maximum at $0.56 \mathrm{eV}$ and $0.76 \mathrm{eV}$ above $\mathrm{E}_{\mathrm{V}}$. Both distributions have a standard deviation of $0.2 \mathrm{eV}$ and electron and holes capture cross sections $\left(\sigma_{\mathrm{e}}, \sigma_{\mathrm{h}}\right)$ 

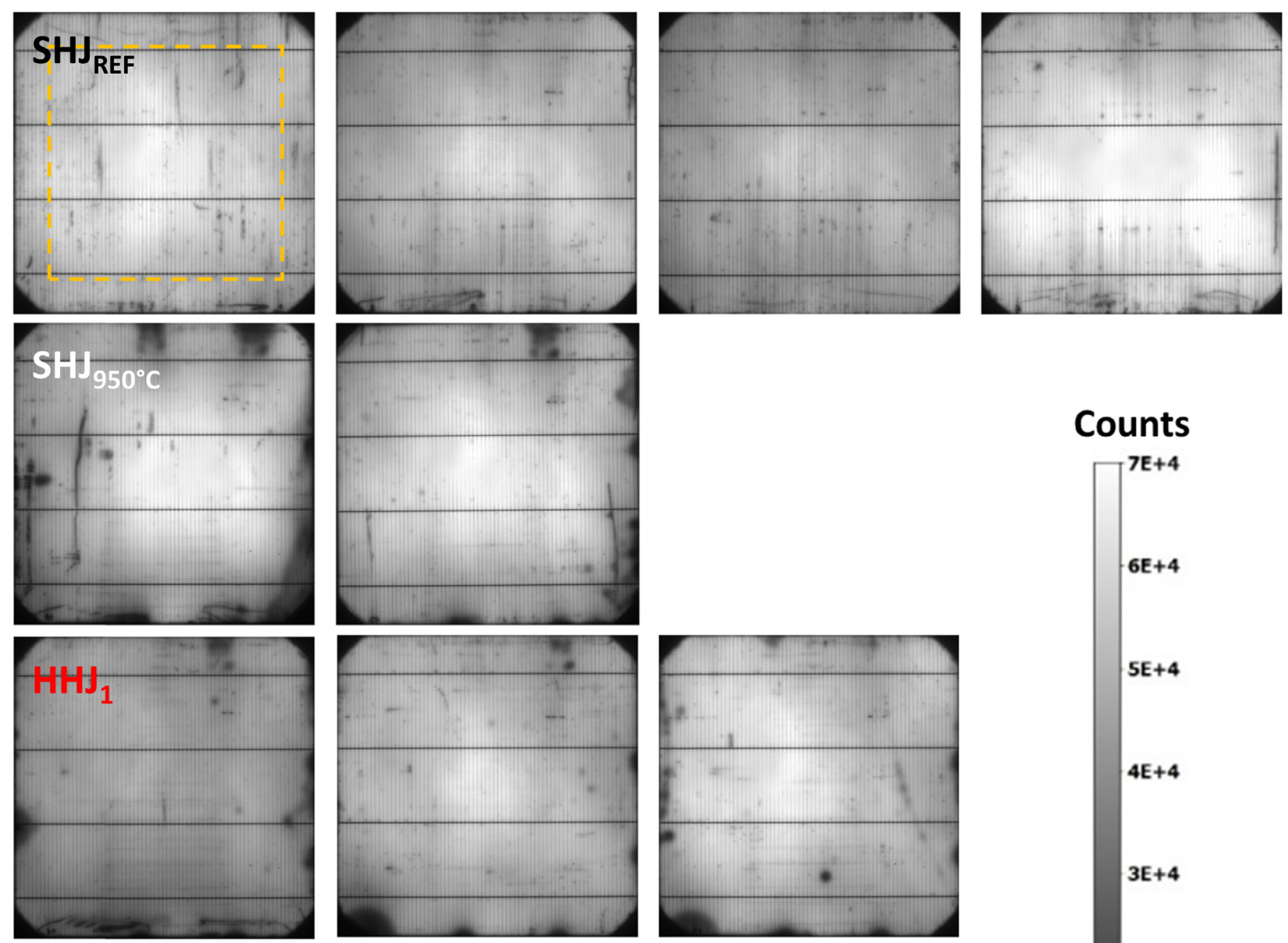

\section{Counts

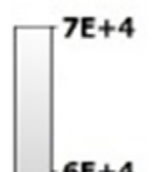

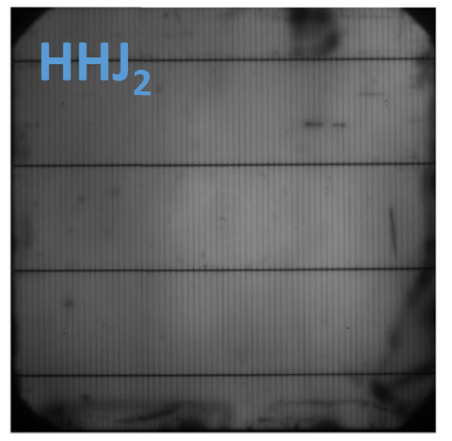
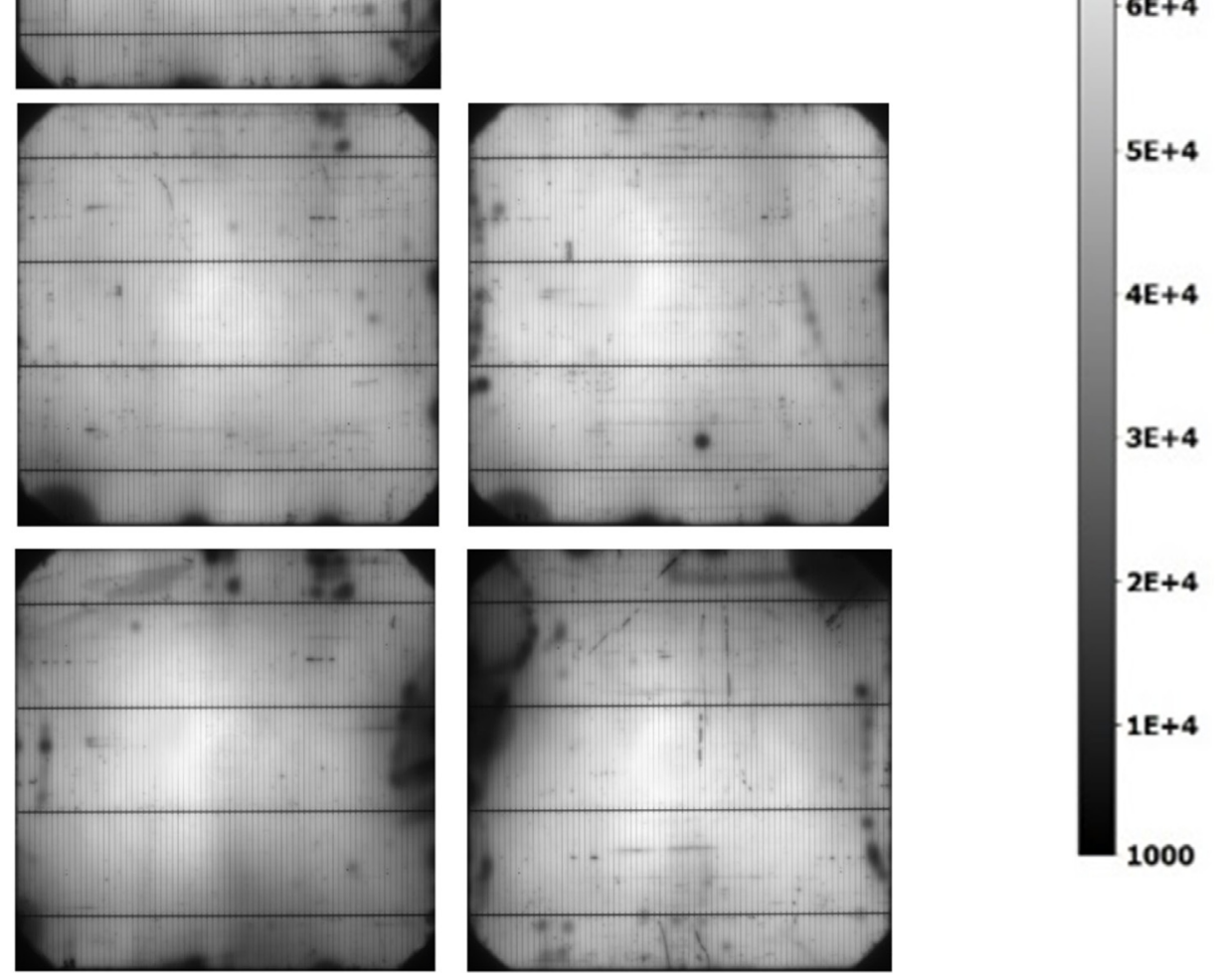

Fig. 8. Photoluminescence images of the processed SHJ and HHJ cells of batch A. The dotted lines represent the active area during the masked IV measurement.

of $1 \times 10^{-14} \mathrm{~cm}^{2}$. The peak values are adjusted to yield targeted equivalent interface defect densities $\left(D_{i t}\right.$ in $\left.\mathrm{cm}^{-2}\right) . D_{i t}$ and external resistances were tuned so that the simulated reference SHJ cell displays performances comparable to that of state-of-the art manufactured cells. $\mathrm{D}_{\text {it }}$ values are set at $5 \times 10^{9}$ and $1 \times 10^{9} \mathrm{~cm}^{-2}$ at the front and back hetero-interface, respectively. External series resistances are set at $0.5 \Omega \mathrm{cm}^{2}$.

In the high quality crystalline substrate (bulk (n) c-Si), recombination centers are modeled with $10^{9} \mathrm{~cm}^{-3}$ neutral defects located at $0.56 \mathrm{eV}$ above $\mathrm{E}_{\mathrm{V}}$ with capture cross sections of $10^{-14} \mathrm{~cm}^{2}$.

In the highly doped added layers defects are also located at $0.56 \mathrm{eV}$ above $\mathrm{E}_{\mathrm{V}}$ and Shockley-Read-Hall recombination dependence on doping is taken into account in the capture time constant: $\tau_{\text {iohigh_doping }}=\tau_{\text {iolow doping }} *\left(\frac{10^{15}}{N_{D}}\right)^{0.4}$,

The lifetime values obtained with this model are below the ones that can be found in literature from other models [52,53]. As a consequence the beneficial effects of the $\left(p^{+}\right)$c-Si layer insertion will not be overestimated.

At high dopant densities (i.e. in the added c-Si layers), the band gap narrowing (BGN) effect makes the $\mathrm{p} \times \mathrm{n}$ product in equilibrium increase above the value that holds at low dopant densities or undoped intrinsic material thus modifying the "intrinsic" carrier concentration following [54] :

$\left(n_{i}^{e f f}\right)^{2}=N_{c} N_{v}^{*} \exp \left(\frac{-\left(E_{g}-\Delta E_{g}^{a p p}\right)}{k T}\right)=n_{i}^{2 *} \exp \left(\frac{\Delta E_{g}^{a p p}}{k T}\right)$, 
Table 2

Simulated layers parameters. Optical and electrical band gap are considered equal.

\begin{tabular}{|c|c|c|c|c|c|c|c|}
\hline Layer parameters & Unit & (p) a-Si:H & (ip) a-Si:H & (n) $\mathrm{a}-\mathrm{Si}: \mathrm{H}$ & (in) $\mathrm{a}-\mathrm{Si}: \mathrm{H}$ & (n) $\mathrm{c}-\mathrm{Si}$ & $\left(\mathrm{p}^{+}\right) \mathrm{c}-\mathrm{Si}$ \\
\hline Thickness & - & $10 \mathrm{~nm}$ & $3 \mathrm{~nm}$ & $25 \mathrm{~nm}$ & $3 \mathrm{~nm}$ & $149.99 \mu \mathrm{m}$ & $0-1000 \mathrm{~nm}$ \\
\hline Band gap & $\mathrm{eV}$ & 1.700 & 1.700 & 1.700 & 1.700 & 1.124 & $1.074-1.124$ \\
\hline Dopant concentration & $\mathrm{cm}^{-3}$ & $6.12 \times 10^{19}$ & 0 & $1.71 \times 10^{19}$ & 0 & $2.0 \times 10^{15}$ & $1-50 \times 10^{17}$ \\
\hline Relative dielectric constant & - & 11.9 & 11.9 & 11.9 & 11.9 & 11.9 & 11.9 \\
\hline Electronic affinity & $\mathrm{eV}$ & 3.824 & 3.824 & 3.824 & 3.824 & 4.05 & 4.05 \\
\hline Electron (hole) mobility & $\mathrm{cm}^{2} \mathrm{~V}^{-1} \mathrm{~s}^{-1}$ & $\begin{array}{l}0.5 \\
(0.5)\end{array}$ & $\begin{array}{l}0.5 \\
(0.5)\end{array}$ & $\begin{array}{l}0.5 \\
(0.5)\end{array}$ & $\begin{array}{l}0.5 \\
(0.5)\end{array}$ & $\begin{array}{l}1321 \\
-461\end{array}$ & $\begin{array}{l}225.2-1321 \\
(96.39-461)\end{array}$ \\
\hline Equivalent density in CB (VB) & $\mathrm{cm}^{-3}$ & $\begin{array}{l}1 \times 10^{20} \\
\left(1 \times 10^{20}\right)\end{array}$ & $\begin{array}{l}1 \times 10^{20} \\
\left(1 \times 10^{20}\right)\end{array}$ & $\begin{array}{l}1 \times 10^{20} \\
\left(1 \times 10^{20}\right)\end{array}$ & $\begin{array}{l}1 \times 10^{20} \\
\left(1 \times 10^{20}\right)\end{array}$ & $\begin{array}{l}2.843 \times 10^{19} \\
\left(2.682 \times 10^{19}\right)\end{array}$ & $\begin{array}{l}1.08 \times 10^{19} \\
\left(1.019 \times 10^{19}\right)\end{array}$ \\
\hline Neutral defect (at $0.56 \mathrm{eV}$ ) concentration & $\mathrm{cm}^{-3}$ & - & - & - & - & 109 & 1014 \\
\hline Electron (hole) capture cross section $\sigma_{e}\left(\sigma_{h}\right)$ & $\mathrm{cm}^{2}$ & - & - & - & - & $\begin{array}{l}\text { Oct-14 } \\
\left(10^{-14}\right)\end{array}$ & $\begin{array}{l}\text { Oct-14 } \\
\left(6.3-30 \times 10^{-14}\right)\end{array}$ \\
\hline CB tail (VB tail) density at Ec (Ev) & $\mathrm{cm}^{-3} \mathrm{eV}^{-1}$ & $\begin{array}{l}2 \times 10^{22} \\
\left(2 \times 10^{22}\right)\end{array}$ & $\begin{array}{l}2 \times 10^{22} \\
\left(2 \times 10^{22}\right)\end{array}$ & $\begin{array}{l}2 \times 10^{22} \\
\left(2 \times 10^{22}\right)\end{array}$ & $\begin{array}{l}2 \times 10^{22} \\
\left(2 \times 10^{22}\right)\end{array}$ & & \\
\hline CB tail (VB tail) Urbach energy & $\mathrm{eV}$ & $\begin{array}{l}0.035 \\
(0.060)\end{array}$ & $\begin{array}{l}0.035 \\
(0.050)\end{array}$ & $\begin{array}{l}0.035 \\
(0.060)\end{array}$ & $\begin{array}{l}0.035 \\
(0.050)\end{array}$ & - & - \\
\hline$\sigma_{e}$ and $\sigma_{h}$ for CB tail & $\mathrm{cm}^{2}$ & $7 \times 10^{-16}$ & $7 \times 10^{-16}$ & $7 \times 10^{-16}$ & $7 \times 10^{-16}$ & - & - \\
\hline$\sigma_{e}$ and $\sigma_{h}$ for VB tail & $\mathrm{cm}^{2}$ & $7 \times 10^{-16}$ & $7 \times 10^{-16}$ & $7 \times 10^{-16}$ & $7 \times 10^{-16}$ & - & - \\
\hline Maximum A- and D-like Gaussian state density & $\mathrm{cm}^{-3} \mathrm{eV}^{-1}$ & $1.20 \times 10^{20}$ & $1.00 \times 10^{17}$ & $2.25 \times 10^{19}$ & $1.00 \times 10^{17}$ & - & - \\
\hline $\begin{array}{l}\text { Position of the A-(D-)like Gaussian } \\
\text { from the valence band edges }\end{array}$ & $\mathrm{eV}$ & $\begin{array}{l}1.450 \\
(1.250)\end{array}$ & $\begin{array}{l}1.450 \\
(1.250)\end{array}$ & $\begin{array}{l}0.850 \\
(0.650)\end{array}$ & $\begin{array}{l}0.850 \\
(0.650)\end{array}$ & - & - \\
\hline Standard deviation of the A- and D-like Gaussian & $\mathrm{eV}$ & 0.19 & 0.19 & 0.19 & 0.19 & - & - \\
\hline$\sigma_{e}\left(\sigma_{h}\right)$ for A-like Gaussian states & $\mathrm{cm}^{2}$ & $\begin{array}{l}3 \times 10^{-15} \\
\left(3 \times 10^{-15}\right)\end{array}$ & $\begin{array}{l}3 \times 10^{-15} \\
\left(3 \times 10^{-15}\right)\end{array}$ & $\begin{array}{l}3 \times 10^{-15} \\
\left(3 \times 10^{-15}\right)\end{array}$ & $\begin{array}{l}3 \times 10^{-15} \\
\left(3 \times 10^{-15}\right)\end{array}$ & - & - \\
\hline$\sigma_{\mathrm{e}}\left(\sigma_{\mathrm{h}}\right)$ for D-like Gaussian states & $\mathrm{cm}^{2}$ & $\begin{array}{l}3 \times 10^{-15} \\
\left(3 \times 10^{-15}\right)\end{array}$ & $\begin{array}{l}3 \times 10^{-15} \\
\left(3 \times 10^{-15}\right)\end{array}$ & $\begin{array}{l}3 \times 10^{-15} \\
\left(3 \times 10^{-15}\right)\end{array}$ & $\begin{array}{l}3 \times 10^{-15} \\
\left(3 \times 10^{-15}\right)\end{array}$ & - & - \\
\hline
\end{tabular}

with $\mathrm{n}_{\mathrm{i}}^{\text {eff }}$ the equilibrium intrinsic carrier concentration at high doping level, $n_{i}$ the equilibrium intrinsic carrier concentration without band gap narrowing effect (i.e. at low doping level), $\mathrm{N}_{\mathrm{c}}\left(\mathrm{N}_{\mathrm{v}}\right)$ the effective density of states in the conduction (valence) band.

The band gap narrowing $\Delta \mathrm{E}_{\mathrm{g}}{ }^{\text {app }}$ is modeled following [55] :

$\Delta E_{g}^{a p p}\left(N_{A}\right)=0.014 * \ln \left(\frac{N_{A}}{1.4 * 10^{17}}\right)$,

Regarding the carrier transport mechanisms, drift-diffusion is considered for homo-interfaces (c-Si/c-Si and a-Si:H/a-Si:H) and thermionic emission together with tunneling are considered for hetero-interfaces (a-Si:H/c-Si).

\subsubsection{Simulation results and discussion}

The solar cell performance parameters extracted from numerical simulation are plotted in Fig. 9 as a function of the interface defect density. It is worth noting that these results were obtained for a front emitter configuration, however we found identical results (within less than 1\%) in the rear emitter configuration (provided one changes the (n) a-Si:H thickness in order to keep the same short circuit current).

While the short circuit current density is almost the same for SHJ and HHJ cells (less than $0.05 \mathrm{~mA} \mathrm{~cm}^{-2}$ difference) one can see the advantage of HHJ cells in the open-circuit voltage at high $\mathrm{D}_{\mathrm{it}}$ and in the fill factor.

For $D_{i t}$ above $10^{9} \mathrm{~cm}^{-2}$, the HHJ cell has a higher $V_{O C}$ value than the SHJ cell. This was evidenced to originate directly from a better field effect passivation that can hinder recombination through interface defects [23]. For $D_{\text {it }}$ below $10^{9} \mathrm{~cm}^{-2}$ recombination at the emitter heterointerface is no longer the limiting recombination path and does not limit the solar cell performance. This is why both SHJ and HHJ cells reach the same $V_{O C}$ value and further reduction of $D_{i t}$ does not improve the solar cell performance.

Regarding the fill factor, an improvement is observed for the HHJ cell in the whole $\mathrm{D}_{\text {it }}$ range. The gain compared to SHJ cells is of $0.8 \%$ abs for $D_{\text {it }}$ values below $5 \times 10^{9} \mathrm{~cm}^{-2}$ and slightly less at higher $D_{i t}$. This gain can be explained, at least partially, by the better field effect passivation. Indeed, field effect improves the minority carrier lifetime at low and medium injection levels, lower than at 1-sun illumination (here below $10^{16} \mathrm{~cm}^{-3}$ ) [40]. Such improvement can be shown on the simulated lifetime curves of symmetrical SHJ and HHJ precursors shown in Fig. 10, which exhibit the same trends as observed experimentally (Figs. 3 and 4). The carrier lifetime for voltages lower than $\mathrm{V}_{\mathrm{OC}}$ and around the maximum power point of the IV curve is higher in the HHJ cell. As a result, a higher proportion of carriers is collected, thus enhancing the FF [41]. Such effect is also confirmed by the improvement in the $\mathrm{pFF}$ values experimentally observed in HHJ cells compared to the SHJ ones.

Simulations can also help explaining the decrease of both the sheet resistance (from TLM measurements on cells precursors) and the series resistance (from IV measurements on the cells) between the HHJ and SHJ cells. Indeed, as can be seen in Fig. 11, in the HHJ cell the Fermi level lies closer to the valence band in both c-Si and a-Si:H regions due to the insertion of the $\left(p^{+}\right) \mathrm{c}$-Si region, Therefore, the hole sheet density in c-Si is larger, explaining the lower sheet resistance observed in Fig. 6. Moreover, the larger hole concentration in a-Si:H also decreases the aSi:H layers resistivity [16].

To quantify the contribution of the change in band bending to the FF decrease, we used the numerical simulations to calculate the resistance of both (i) a-Si:H and ( $p$ ) a-Si:H layers under illumination at the maximum power point; we focus on the a-Si:H layers since they are by far the most resistive one [16]. As expected from the band diagram of Fig. 11, the calculated resistances in the a-Si:H layers are lower for the HHJ cell, $0.43 \Omega \mathrm{cm}^{2}$ for the sum of both (i) and (p) a-Si:H layers, compared to $0.56 \Omega \mathrm{cm}^{2}$ for the SHJ cell. The series resistance of the cell, $R_{S}$ Cell, is also lower for the HHJ cell while the FF value is larger. However the decrease in $R_{S}$ cell is more pronounced, suggesting that the resistance of the a-Si:H layers cannot solely explain the decrease in $\mathrm{R}_{\mathrm{S}}$ Cell and the increase of FF from the SHJ to the HHJ cell (Table 3).

This is confirmed by the numerical results obtained on the $\mathrm{SHJ}_{\text {ajusted }}$ cell, where we only increased the a-Si:H mobility so as to ajust the a$\mathrm{Si}: \mathrm{H}$ resistance at the same level as in the HHJ cell $\left(0.43 \Omega \mathrm{cm}^{2}\right)$. Indeed, for this cell we observe a decrease of $R_{S}$ cell and an increase of FF compared to the SHJ cell, but the values are still a bit behind those of the HHJ cell, suggesting that transport across the interface through thermoionic effect is also favoured in the HHJ cell and contributes to the increase in FF. 


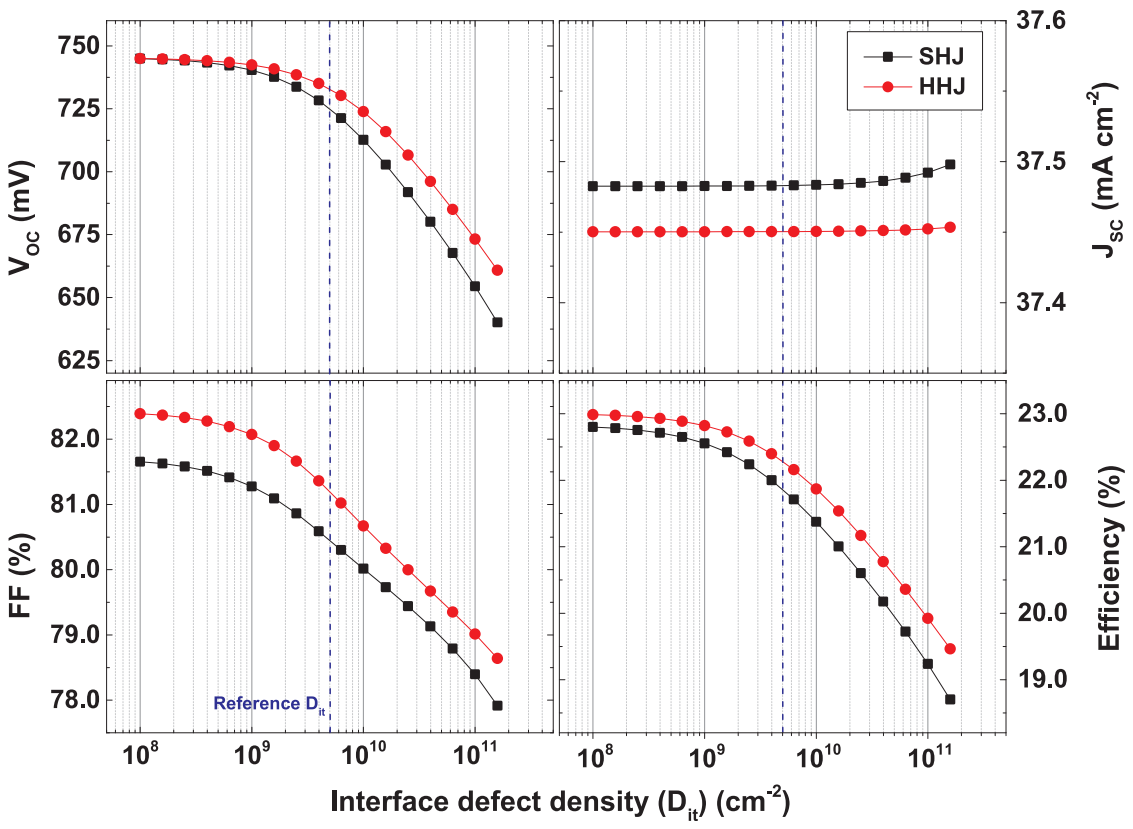

Fig. 9. Simulated SHJ and HHJ solar cells performance, open-circuit voltage $\left(\mathrm{V}_{\mathrm{oc}}\right)$, short circuit current density $\left(\mathrm{J}_{\mathrm{SC}}\right)$, fill factor (FF) and efficiency as a function of interface defect density $\left(D_{i t}\right)$ at the emitter side. The vertical blue dashed line marks the reference $D_{\text {it }}$ considered for both the SHJ and HHJ cells.

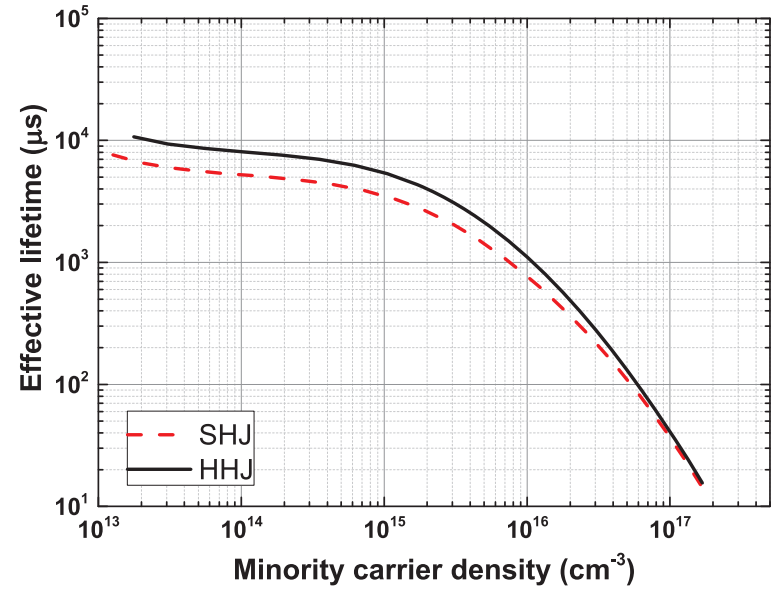

Fig. 10. Simulated injection dependent lifetime curves for HHJ and SHJ cells (plain lines and dashed lines, respectively).

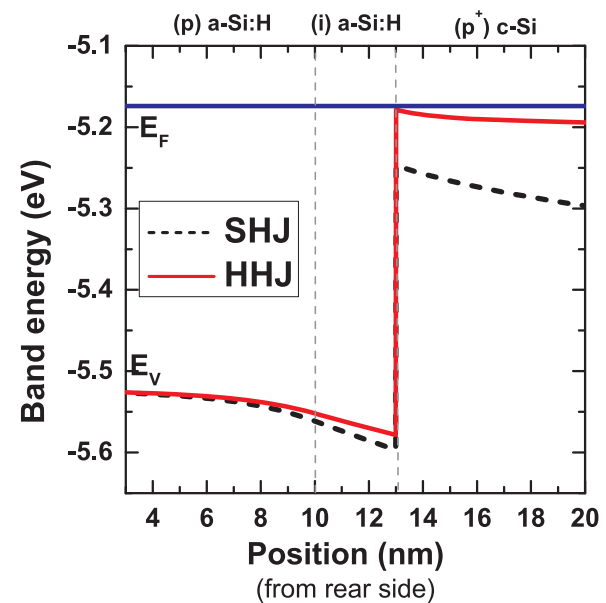

Fig. 11. Equilibrium valence band diagrams of the SHJ and HHJ cells around the hetero-interface.
Table 3

Photovoltaic parameters (open-circuit voltage, short circuit current density, fill factor and efficiency) and resistances extracted from simulations. $\mathrm{R}_{\mathrm{a}} \mathrm{Si:H}$ is the resistance of the emitter a-Si:H layers, at the maximum power point under illumination, $R_{S \text { cell }}$ is the series resistances of the cell. Values are shown for the three simulated cells: SHJ, HHJ and $\mathrm{SHJ}_{\text {adjusted }}$, for which the a-Si:H mobility has been adjusted so as to have the same $\mathrm{R}_{\mathrm{a} \text { Si:H }}$ value as in the HHJ cell.

\begin{tabular}{lllll}
\hline & Unit & SHJ & SHJ $_{\text {adjusted }}$ & HHJ \\
\hline $\mathbf{V}_{\text {oc }}$ & $\mathrm{mV}$ & 725 & 725 & 733 \\
$\mathbf{J}_{\text {SC }}$ & $\mathrm{mA} \mathrm{cm}^{-2}$ & 37.5 & 37.5 & 37.5 \\
$\mathbf{F F}$ & $\%$ & 80.4 & 80.9 & 81.2 \\
Efficiency & $\%$ & 21.9 & 22.0 & 22.3 \\
$\mathbf{R}_{\text {a-Si:H }}$ & $\Omega \mathrm{cm}^{2}$ & 0.56 & 0.43 & 0.43 \\
$\mathbf{R}_{\text {s cell }}$ & $\Omega \mathrm{cm}^{2}$ & 1.08 & 0.94 & 0.74 \\
\hline
\end{tabular}

Note that simulation results predict that the open-circuit voltage of HHJ cells should be slightly larger than that of SHJ cells, which is not observed experimentally. This is because in the simulations the interface defect density was kept at the same value for SHJ and HHJ cells. Experimentally, although we have improved the quality of the interface compared to previous work, it is likely that our HHJ cells still have a a higher defect density at the heterointerface compared to the SHJ cells, which counterbalances the expected benefit from field effect passivation on the open-circuit voltage. Finally, also note that the absolute values of extracted photovoltaic parameters are slightly different in the simulated and experimental results. Indeed, the FF and efficiency improvements predicted from numerical simulation in HHJ cells are less pronounced in the experimental results. In the simulations, we have considered a $10 \mathrm{~nm}$ thick layer homogeneously doped at $5 \times 10^{18}$ $\mathrm{cm}^{-3}$ corresponding to a dose of $5 \times 10^{12} \mathrm{~cm}^{-2}$. Experimentally, $\mathrm{HHJ}_{1}$ and $\mathrm{HHJ}_{2}$ homo-emitters have doses in the same order of magnitudes ( 0.2 and $1 \times 10^{13} \mathrm{~cm}^{-2}$, respectively). However, the dose is distributed over more than $100 \mathrm{~nm}$. Therefore, the difference in doping profiles is likely to explain discrepancies between simulations and experiments.

\section{Conclusion}

The first proof of concept of homo-heterojunction (HHJ) solar cells has been demonstrated. The novel architecture contains an additional 
$\left(p^{+}\right)$c-Si region at the hetero-interface emitter side of an n-type silicon heterojunction solar cell (SHJ). From lifetime measurements on symmetrical precursors, a limited (i) a-Si:H passivation on the $\left(p^{+}\right) \mathrm{c}-\mathrm{Si}$ region has been evidenced and found to be directly related to the boron surface concentration. This phenomenon is critical for the HHJ processing since the lower chemical passivation can counter-balance the improved field effect. Nevertheless, we succeeded in taking benefit from the enhanced field effect to improve the effective carrier lifetime at low injection levels by considering lowly doped $\left(p^{+}\right)$c-Si regions. This allowed us to produce n-type HHJ large area solar cells with FF and efficiencies slightly surpassing that of regular SHJ cells. From both experiments and numerical simulations, the FF improvement has been correlated to the field effect enhancement but also to the series resistance decrease arising from the modified band bending at the heterointerface.

Although we have observed efficiency improvements with the HHJ architecture as compared to the SHJ one, these are the very first results obtained for HHJ solar cells so there is space for further improvements in order to maximize the homo-heterojunction benefits. For instance, there are many optimizations to be done concerning boron profiles management or a-Si:H layers properties tuning. The issue of annealing damages on the substrates should also be addressed to maximize the HHJ cells efficiency while decreasing its costs before evaluating the architecture potential to decrease the price of electricity.

\section{Acknowledgements}

The authors would like to acknowledge the French Environment and Energy Management Agency (ADEME) for funding this work. The authors thank the support of J. Le Perchec and P. Mur from CEA-LETI.

\section{References}

[1] K. Masuko, M. Shigematsu, T. Hashiguchi, D. Fujishima, M. Kai, N. Yoshimura, T. Yamaguchi, Y. Ichihashi, T. Mishima, N. Matsubara, T. Yamanishi, T. Takahama, M. Taguchi, R. Maruyama, S. Okamoto, Achievement of more than 25\% conversion efficiency with crystalline silicon heterojunction solar cell, IEEE J. Photovolt. 4 (2014) 1433-1435, http://dx.doi.org/10.1109/JPHOTOV.2014.2352151.

[2] J.B. Heng, J. Fu, B. Kong, Y. Chae, W. Wang, Z. Xie, A. Reddy, K. Lam, C. Beitel, C. Liao, C. Erben, Z. Huang, Z. Xu, > 23.1\% High efficiency tunnel oxide junction bifacial solar cell with electroplated Cu gridlines, in : Proceedings of the 29th European Photovoltaic Solar Energy Conference and Exhibition, Amsterdam, The Netherlands, 2014, pp. 492-496, 〈http://dx.doi.org/10.4229/EUPVSEC.201420142CO.1.2>.

[3] T. Kinoshita, D. Fujishima, A. Yano, A. Ogane, S. Tohoda, K. Matsuyama, Y. Nakamura, N. Tokuoka, H. Kanno, H. Sakata, M. Taguchi, E. Maruyama, The approaches for high efficiency HIT solar cell with very thin $(<100 \mu \mathrm{m})$ silicon wafer over 23\%, in: Proceedings of the 26th European Photovoltaic Solar Energy Conference and Exhibition, Hamburg, Germany, 2011, pp. 871-874, 〈http://dx.doi. org/10.4229/26thEUPVSEC.2011-2AO.2.6>.

[4] J.L. Hernández, K. Yoshikawa, A. Feltrin, N. Menou, N. Valckx, E. Van Assche D. Schroos, K. Vandersmissen, H. Philipsen, J. Poortmans, High efficiency silverfree heterojunction silicon solar cell, Jpn. J. Appl. Phys. 51 (2012) 10NA04, http:// dx.doi.org/10.1143/JJAP.51.10NA04.

[5] D. Bätzner, Y. Andrault, L. Andreetta, A. Buechel, W. Frammelsberger, C. Guerin, N. Holm, D. Lachenal, J. Meixenberger, P. Papet, B. Rau, B. Strahm, G. Wahli, F. Wuensch, Characterisation of over $21 \%$ efficient silicon heterojunction cells developed at Roth \& Rau Switzerland, in: Proceedings of the 26th European Photovoltaic Solar Energy Conference and Exhibition, Hamburg, Germany, 2011, pp. 1073-1075, 〈http://dx.doi.org/10.4229/26thEUPVSEC.2011-2CO.14.6〉.

[6] A. Descoeudres, L. Barraud, S. De Wolf, B. Strahm, D. Lachenal, C. Guérin, Z.C. Holman, F. Zicarelli, B. Demaurex, J. Seif, J. Holovsky, C. Ballif, Improved amorphous/crystalline silicon interface passivation by hydrogen plasma treatment, Appl. Phys. Lett. 99 (2011) 123506, http://dx.doi.org/10.1063/1.3641899.

[7] D. Muñoz, T. Desrues, A.-.S. Ozanne, N. Nguyen, S. de Vecchi, F. Souche, S. Martin de Nicolàs, C. Denis, P.-.J. Ribeyron, Progress on high efficiency standard and interdigitated back contact silicon heterojunction solar cells, in: Proceedings of the 26th European Photovoltaic Solar Energy Conference and Exhibition, Hamburg, Germany, 2011, pp. 861-864, 〈http://dx.doi.org/10.4229/26thEUPVSEC.20112AO.2.3>

[8] D. Adachi, J.L. Hernández, K. Yamamoto, Impact of carrier recombination on fill factor for large area heterojunction crystalline silicon solar cell with $25.1 \%$ efficiency, Appl. Phys. Lett. 107 (2015) 233506, http://dx.doi.org/10.1063/1. 4937224.

[9] K. Yoshikawa, H. Kawasaki, W. Yoshida, T. Irie, K. Konishi, K. Nakano, T. Uto,
D. Adachi, M. Kanematsu, H. Uzu, K. Yamamoto, Silicon heterojunction solar cell with interdigitated back contacts for a photoconversion efficiency over $26 \%$, Nature, Energy 2 (2017) 17032, http://dx.doi.org/10.1038/nenergy.2017.32 (| www.nature.com/natureenergy).

[10] K. Yamamoto, D. Adachi, K. Yoshikawa, W. Yoshida, T. Irie, K. Konishi, T. Fujimoto, H. Kawasaki, M. Kanematsu, H. Ishibashi, T. Uto, Y. Takahashi, T. Terashita, G. Koizumi, N. Nakanishi, M. Yoshimi, Record-Breaking Efficiency BackContact Heterojunction Crystalline Si Solar Cell and Module, in: Proceedings of the 33rd European Photovoltaic Solar Energy Conference and Exhibition, Amsterdam, 2017, pp. 201 - 204, doi: 10.4229/EUPVSEC.20172017-2BP.1.1.

[11] S. De Wolf, A. Descoeudres, Z.C. Holman, C. Ballif, High-efficiency silicon heterojunction solar cells: a review, Green 2 (2012) 7-24, http://dx.doi.org/10.1515/ green-2011-0018.

[12] M. Schmidt, L. Korte, A. Laades, R. Stangl, Ch Schubert, H. Angermann, E. Conrad, Kv Maydell, Physical aspects of a-Si: h/c-si hetero-junction solar cells, Thin Solid Films 515 (2007) 7475-7480, http://dx. doi.org/10.1016/j.tsf.2006.11.087.

[13] H. Angermann, T.F. Schulze, E. Conrad, J. Rappich, L. Korte, M. Schmidt, Cleaning and passivation of structured n-type si substrates: preparation and interface properties of a-Si:H/c-si hetero solar cells, in: Proceedings of the 23rd European Photovoltaic Solar Energy Conference and Exhibition, Valencia, Spain, 2008, pp. 1422-1426, 〈http://dx.doi.org/10.4229/23rdEUPVSEC.2008-2CV.4.31〉.

[14] Liu Jian, Huang Shihua, He Lü, Simulation of a high-efficiency silicon-based heterojunction solar cell, J. Semicond. 36 (2015) 044010, http://dx.doi.org/10.1088/ 1674-4926/36/4/044010.

[15] R. Varache, O.N. Aguila, A. Valla, N. Nguyen, D. Muñoz, Role of the front electron collector in rear emitter silicon heterojunction solar cells, IEEE J. Photovolt. 5 (2015) 711-717, http://dx.doi.org/10.1109/JPHOTOV.2015.2400226.

[16] R. Lachaume, W. Favre, P. Scheiblin, X. Garros, N. Nguyen, J. Coignus, D. Munoz, G. Reimbold, Influence of a-Si: h/ito interface properties on performance of heterojunction solar cells, Energy Procedia 38 (2013) 770-776, http://dx.doi.org/10. 1016/j.egypro.2013.07.345.

[17] F. Wang, X. Zhang, L. Wang, Y. Jiang, C. Wei, S. Xu, Y. Zhao, Improved amorphous/ crystalline silicon interface passivation for heterojunction solar cells by low-temperature chemical vapor deposition and post-annealing treatment, Phys. Chem. Chem. Phys. 16 (2014) 20202-20208, http://dx.doi.org/10.1039/C4CP02212B.

[18] L. Serenelli, R. Chierchia, M. Izzi, M. Tucci, L. Martini, D. Caputo, R. Asquini, G. de Cesare, Hydrogen plasma and thermal annealing treatments on a-Si:H thin film for c-Si surface passivation, Energy Procedia 60 (2014) 102-108, http://dx.doi.org/10. 1016/j.egypro.2014.12.350.

[19] A. Florakis, T. Janssens, J. Poortmans, W. Vandervorst, Process modeling for doped regions formation on high efficiency crystalline silicon solar cells, J. Comput. Electron. 13 (2014) 95-107, http://dx.doi.org/10.1007/s10825-013-0487-2.

[20] R. Janssen, A. Janotta, D. Dimova-Malinovska, M. Stutzmann, Optical and electrical properties of doped amorphous silicon suboxides, Phys. Rev. B 60 (1999) 13561-13572, http://dx.doi.org/10.1103/physrevb.60.13561.

[21] M. Mews, M. Liebhaber, B. Rech, L. Korte, Valence band alignment and hole transport in amorphous/crystalline silicon heterojunction solar cells, Appl. Phys. Lett. 107 (2015) 013902, http://dx.doi.org/10.1063/1.4926402.

[22] T. Mueller, J. Wong, A.G. Aberle, Heterojunction silicon wafer solar cells using amorphous silicon suboxides for interface passivation, Energy Procedia 15 (2012) 97-106, http://dx.doi.org/10.1016/j.egypro.2012.02.012.

[23] T. Carrere, R. Varache, D. Muñoz, J.P. Kleider, Insertion of a thin highly doped crystalline layer in silicon heterojunction solar cells: simulation and perspectives towards a highly efficient cell concept, J. Renew. Sustain. Energy 7 (2015) 011202, http://dx.doi.org/10.1063/1.4908189.

[24] S. Zhong, X. Hua, W. Shen, Simulation of high-efficiency crystalline silicon solar cells with homo-hetero junctions, IEEE Trans. Electron Devices 60 (2013) 2104-2110, http://dx.doi.org/10.1109/TED.2013.2259830.

[25] M. Mikolášek, P. Príbytný, D. Donoval, J. Marek, A. Chvála, M. Molnár, J. Kovác, Suppression of interface recombination by buffer layer for back contacted silicon heterojunction solar cells, Appl. Surf. Sci. 312 (2014) 145-151, http://dx.doi.org/ 10.1016/j.apsusc. 2014.05.110.

[26] B. Demaurex, (2014). Passivating contacts for homojunction solar cells using a$\mathrm{Si}: \mathrm{H} / \mathrm{c}-\mathrm{Si}$ hetero-interfaces, Thèse École polytechnique fédérale de Lausanne EPFL, no. 6392. 〈http://dx.doi.org/10.5075/epfl-thesis-6392〉.

[27] Yu-Hsien Lin, Yung-Chun Wu, Hsin-Chiang You, Chun-Hao Chen, Ping-Hua Chen, Yi-He Tsai, Yi-Yun Yang, K.S. Chang-Liao, Silicon heterojunction solar cells using AlOx and plasma-immersion ion implantation, Energies 7 (2014) 3653-3663, http://dx.doi.org/10.3390/en7063653.

[28] T. Carrere, R. Varache, J. Le Perchec, C. Denis, D. Muñoz, J.-P. Kleider, Silicon bulk issues during processing of homo-heterojunction solar cells, Energy Procedia 77 (2015) 451-457, http://dx.doi.org/10.1016/j.egypro.2015.07.064.

[29] F. Jay F, Nouveaux substrats de silicium cristallin destinés aux cellules photovoltaïques à haut rendement : cas du silicium mono-like et du dopage aux donneurs thermiques liés à l'oxygène pour les cellules à hétérojonction de silicium, thèse de l'Université Grenoble Alpes, NNT:2016GREAI010, 2016.

[30] A. Lanterne, S. Gall, Y. Veschetti, R. Cabal, M. Coig, F. Milési, A. Tauzin, High efficiency fully implanted and co-annealed bifacial n-type solar cells, Energy Procedia 38 (2013) 283-288, http://dx.doi.org/10.1016/j.egypro.2013.07.279.

[31] B. Hoex, J.J.H. Gielis, M.C.M. van de Sanden, W.M.M. Kessels, On the c-Si surface passivation mechanism by the negative-charge-dielectric $\mathrm{Al}_{2} \mathrm{O}_{3}$, J. Appl. Phys. 104 (2008) 113703, http://dx.doi.org/10.1063/1.3021091.

[32] R.A. Sinton, A. Cuevas, Contactless determination of current-voltage characteristics and minority-carrier lifetimes in semiconductors from quasi-steady-state photoconductance data, Appl. Phys. Lett. 69 (1996) 2510-2512, http://dx.doi.org/10. 1063/1.117723. 
[33] S. Bowden, V. Yelundur, A. Rohatgi, Implied- $\mathrm{V}_{\mathrm{oc}}$ and Suns $-\mathrm{V}_{\mathrm{oc}}$ measurements in multicrystalline solar cells, in: Proceedings of the 29th IEEE Photovoltaic Specialists Conference (PVSC), New Orleans, Louisiana, 2002, pp. 371-374, 〈http://dx.doi. org/10.1109/PVSC.2002.1190536>.

[34] D.L. Meier, D.K. Schroder, Contact resistance: its measurement and relative importance to power loss in a solar cell, IEEE Trans. Electron Devices 31 (1984) 647-653, http://dx.doi.org/10.1109/T-ED.1984.21584.

[35] L.K. Mak, C.M. Rogers, D.C. Northrop, Specific contact resistance measurements on semiconductors, J. Phys. E: Sci. Instrum. 22 (1989) 317-321, http://dx.doi.org/10. 1088/0022-3735/22/5/010.

[36] E. Rimini, Ion Implantation: basics to device fabrication, The Springer International Series in Engineering and Computer Science 293 Springer, 1995, http://dx.doi.org/ 10.1007/978-1-4615-2259-1.

[37] S. Harrison, A. Danel, C. Roux, D. Heslinga, F. Ozanne, D. Muñoz, P.J. Ribeyron, CEA-INES Heterojunction Solar Cell LabFab Industrial Pilot Line: Production Capability Demonstration, Roadmap to 22\% Mean Efficiency, in: Proceedings of the 29th European Photovoltaic Solar Energy Conference and Exhibition, Amsterdam, The Netherlands, pp. 1049-1052, 〈http://dx.doi.org/10.4229/EUPVSEC. 20142014-2AV.3.33>, 2014.

[38] M. Bivour, M. Reusch, S. Schroer, F. Feldmann, J. Temmler, H. Steinkemper, M. Hermle, Doped layer optimization for silicon heterojunctions by injection-leveldependent open-circuit voltage measurements, IEEE J. Photovolt. 4 (2014) 566-574, http://dx.doi.org/10.1109/JPHOTOV.2013.2294757.

[39] T. Trupke, R.A. Bardos, M.D. Abbott, P. Würfel, E. Pink, Y. Augarten, F.W. Chen, K. Fisher, J.E. Cotter, M. Kasemann, M. Rüdiger, S. Kontermann, M.C. Schubert, M. The, S.W. Glunz, W. Warta, D. Macdonald, J. Tan, A. Cuevas, J. Bauer, R. Gupta, O. Breitenstein, G. Tarnowski, H.P. Hartmann, D.H. Neuhaus, J.M. Fernandez, Progress with luminesence imaging for the characterisation of silicon wafers and solar cells, in: Proceedings of the 22nd European Photovoltaic Solar Energy Conference and Exhibition, Milan, Italy, 2007, pp. 22-31.

[40] D. Pysch, A. Mette, S.W. Glunz, A review and comparison of different methods to determine the series resistance of solar cells (6 November), Sol. Energy Mater. Sol. Cells 91 (18) (2007) 1698-1706.

[41] S.W. Glunz, D. Biro, S. Rein, W. Warta, Field-effect passivation of the $\mathrm{SiO}_{2} \mathrm{Si}$ interface, J. Appl. Phys. 86 (1999) 683-691, http://dx.doi.org/10.1063/1.370784.

[42] A. Descoeudres, Z.C. Holman, L. Barraud, S. Morel, B. Demaurex, J. Geissbühler, J. P. Seif, S. De Wolf, C. Ballif, Silicon heterojunction solar cells on n-and p-type wafers with efficiencies above 20\%, in: Proceedings of the 27th European Photovoltaic Solar Energy Conference and Exhibition, Frankfurt, Germany, 2012, pp. 647-51, 〈http://dx.doi.org/10.4229/27thEUPVSEC.2012-2BO.6.2〉.
[43] F. Jay, J. Veirman, N. Najid, D. Muñoz, S. Dubois, A. Jouini, Exclusively thermal donor-doped $\mathrm{Cz}$ wafers for silicon heterojunction solar cell technology, Energy Procedia 55 (2014) 533-538, http://dx.doi.org/10.1016/j.egypro.2014.08.020.

[44] H.J. Stein, S.K. Hahn, S.C. Shatas, Rapid thermal annealing and regrowth of thermal donors in silicon, J. Appl. Phys. 59 (1986) 3495-3502, http://dx.doi.org/10.1063/ 1.336820 .

[45] M. Tomassini, J. Veirman, R. Varache, E. Letty, S. Dubois, Y. Hu, Ø. Nielsen, Recombination activity associated with thermal donor generation in monocrystalline silicon and effect on the conversion efficiency of heterojunction solar cells, J. Appl. Phys. 119 (2016) 084508, http://dx.doi.org/10.1063/1.4942212.

[46] J. Bullock, D. Yan, Y. Wan, A. Cuevas, B. Demaurex, A. Hessler-Wyser, S. De Wolf, Amorphous silicon passivated contacts for diffused junction silicon solar cells, J. Appl. Phys. 115 (2014) 163703, http://dx.doi.org/10.1063/1.4872262.

[47] K. Carstens, M. Dahlinger, E. Hoffmann, J.R. Kähler, R. Zapf-Gottwick, J.H. Werner, Universal passivation for $\mathrm{p}++$ and $\mathrm{n}++$ areas on IBC solar cells, Energy Procedia 77 (2015) 779-785, http://dx.doi.org/10.1016/j.egypro.2015.07.110.

[48] J.P. Kleider, A.S. Gudovskikh, P. Roca i Cabarrocas, Determination of the conduction band offset between hydrogenated amorphous silicon and crystalline silicon from surface inversion layer conductance measurements, Appl. Phys. Lett. 92 (2008) 162101, http://dx.doi.org/10.1063/1.2907695.

[49] N.D. Arora, J.R. Hauser, D.J. Roulston, Electron and hole mobilities in silicon as a function of concentration and temperature, IEEE Trans. Electron Devices ED 29 (1982) 292-295, http://dx.doi.org/10.1109/T-ED.1982.20698.

[50] R. Varache, J.P. Kleider, M.E. Gueunier-Farret, L. Korte, Silicon heterojunction solar cells: optimization of emitter and contact properties from analytical calculation and numerical simulation, Mater. Sci. Eng. B 178 (2013) 593-598, http://dx.doi.org/ 10.1016/j.mseb.2012.11.011.

[51] M. Powell, S. Deane, Defect-pool model and the hydrogen density of states in hydrogenated amorphous silicon, Phys. Rev. B 53 (1996) 10121-10132, http://dx.doi org/10.1103/PhysRevB.53.10121.

[52] J.G. Fossum, R.P. Mertens, D.S. Lee, J.F. Nijs, Carrier recombination and lifetime in highly doped silicon, Solid-State Electron. 26 (1983) 569-576, http://dx.doi.org/ 10.1016/0038-1101(83)90173-9.

[53] S. Bellone, G. Busatto, C.M. Ransom, Recombination measurement of n-type heavily doped layer in high/low silicon junctions, IEEE Trans. Electron Devices ED 38 (1991) 532-537, http://dx.doi.org/10.1109/16.75163.

[54] S.M. Sze, Physics of Semiconductor Devices, 2nd ed., Wiley, 1998.

[55] A. Cuevas, P.A. Basore, G. Giroult-Matlakowski, C. Dubois, Surface recombination velocity of highly doped n-type silicon, J. Appl. Phys. 80 (1996) 3370-3375, http:// dx.doi.org/10.1063/1.363250. 